\title{
Impacts of infrastructure development in the villages of Batang Regency in terms of social, economy, education, and health
}

\author{
Muhammad Fajri ${ }^{1}$ and Ayomi Rarasati ${ }^{1, *}$ \\ ${ }^{1}$ Department of Civil Engineering, Faculty of Engineering, Universitas Indonesia, Depok, Indonesia
}

\begin{abstract}
The increase of village fund since 2015 led to the Indonesian government's expectation for economic growth and more infrastructure development in villages, with the hope that the villagers' quality of life will improve. This research aimed at analyzing the impacts of infrastructure development in Batang Regency, Central Java in terms of social, economy, education, and health aspects. Data was collected via structured interviews. The focus of the research is to identify the differences of impacts on infrastructure development based on 2 categories. The first category is the 3 geographical zones: the borders of the north coast Trans Java highway network (Pantura), mountainous area and coast area. The second category is based on the villagers' duration of stay in their village: more than 10 years and less than 10 years. Based on the geographical zone research results, there were differences found in the impacts on social aspects, but none in the economy, education, health and education aspects. In the length of stay category, there were no differences in the impacts resulted from the infrastructure development on either the social, economy, education, or health aspects.
\end{abstract}

\section{Introduction}

Public work infrastructure is a form of government service to increase its citizens' welfare since infrastructure can boost national and regional development. Infrastructure also contributes to the economic growth and the improvement in the quality of life by increasing consumption, labour productivity, access to employment, and welfare [1].

The increase in village fund from IDR 20.7 trillion in 2015 to IDR 46.9 trillion in 2016 and IDR 81.1 trillion in 2017 meant that every village was expected to manage more than IDR 1 billion each [2]. In 2017, this fund was still aimed at boosting economic growth so that the villagers' buying power would strengthen, those with local raw materials would receive income, and the infrastructure and facilities would increase agricultural production as well as improving the distribution of goods [3].

Batang Regency of Central Java consists of 248 villages. It is highly potential in agriculture, fisheries, industries, and tourism due to the 3 geographical zones namely mountainous, coasts, and low lands located along the north coast trans Java highway network called Pantura. In line with the strengthening of village infrastructure development especially in Batang Regency, an impact review is required to evaluate the plan and to ensure that it complies with Law No. 6 Year 2016 article 78. This article states that Village Development is intended to improve village community welfare and human life quality as well as poverty reduction through basic needs fulfilment, village infrastructure development, local economic development potential, and the sustainable use of natural resources and the environment.

\section{Literature review}

According to the Republic of Indonesia's Presidential Regulations No. 38 Year 2015 infrastructure is "the technical, physical, hardware, and software system facilities required to provide services to society and to support structural networks that enable the improvement of economic and social development". Types of village infrastructure covered in the 2014-2015 Rural Infrastructure Development Program (RIDP) are those supporting accessibility such as roads and bridges, those supporting food production such as irrigation, and those fulfilling the villagers' basic needs such as drinking water and sanitation.

In accordance with Law No 26 Year 2008 on Spatial Planning, a village refers to an area with its main activities in agriculture. In 2011, the National Development Planning Ministry (BAPPENAS) declared a village as an area with agriculture as its main activities, which include natural resources management for functions namely residential area, services, administration, social services, and economic activities. Its community is marked with a strong emotional bond among villagers, a sense of sacrifice, respect, and preservation of common dignity

\footnotetext{
*Corresponding author: ayomi@eng.ui.ac.id
} 
and happiness, with equal rights and obligations for all [4]. Therefore, a village is briefly defined as an area with agriculture as its main activity and the presence of a strong social bond among villagers.

Impacts according to Kamus Besar Bahasa Indonesia (KBBI) are a strong influence that brings both positive and negative changes. Development is a deliberate economic, social and cultural transformation through policies and strategies towards the desired goals [5]. The impacts of development can expand into ideology, politics, economy, and social cultural and security aspects [6]. Development not only brings positive impacts but also negative ones if the process does not take into consideration community's needs and problems [7]. This means that infrastructure can be a fundamental effort to alleviate poverty [8].

Development will affect social change [13]. Social impact assessment is important to evaluate the positive and negative impacts, where the analysis of the study depends on the scale of the project and the potential generated. Negative impacts can cause social problems that arise due to differences in values that exist in society with existing reality. Social problems can be caused by economic factors such as unemployment and poverty, cultural factors such as adolescent bad behaviour, biological factors such as infectious diseases, and psychological factors such as neurological diseases or cults [15].

The impact of infrastructure development can be seen from social activities, level of crowd, and lifestyle of the community [7]. Social activities can take the form of community service, where this form of activity can form mutual trust between citizens in dealing with common problems, in the form of cooperation between individuals, between groups, and individuals and groups. The impact of infrastructure development can reduce the intensity of social activities in the community. The level of crowd, which is caused by complete facilities and infrastructure, can be an attraction for the community to a place. Therefore, the number of people in a certain place at certain times is more than usual. Another possible impact is the depletion of religious-based values and culture [13], the transition of jobs from agriculture to non-agriculture, the fading of kinship between citizens and the existence of conflict [17]. Conflict can be caused by new comers who do not care about the existing condition of the village and do not provide employment opportunities for local villagers.

Although infrastructure development can increase the number of small and medium enterprises, it can also increase the number of unemployed [17], so that it can affect job losses for some people [13], as a result of road infrastructure development.

An increase in school development can have a positive impact and is also a preparation in building human resources after the infrastructure is built [13]. With infrastructure development, there is also an increase in student attendance and an increase in school graduation [17].

Batang Regency is an administrative area consisting of 15 districts and 248 Village/sub-districts. It is $78,864.16 \mathrm{Ha}$, in which $28.37 \%$ is rice field. In terms of borders, Java Sea is to the north, Kendal Regency is to the east, Wonosobo Regency is to the south and Pekalongan Regency is to the west. Batang Regency's topography comprises of three areas namely coastal, mountainous and lowland areas. Most land is used for forestry, plantation and agriculture. The 2010 census showed that Batang Regency's 2016 population was 749,720, in which there were 515,905 people in the 15-64 age groups. These numbers show that there is younger productive population compared to old or non-productive ones.

\section{Research methods}

\subsection{Research process}

This research aimed at analyzing the impacts of infrastructure development in Batang Regency, Central Java in terms of social, economy, education, and health aspects.This research started with the search for a background to identify existing problems. Afterwards, relevant theories were collected to obtain development impact indicators. These indicators were used to collect data through a questionnaire survey. The data is then processed to identify the impacts of infrastructure development based on 2 categories: the first category is based on the 3 geographical zones namely that along Pantura, mountainous and coastal landscapes. The second category is based on the villagers' length of stay i.e. more than 10 years or less than 10 years.

\subsection{Data collection method}

This research uses the data collection method of structured interview technique. Structured interview is a process where the respondents answer the interviewers' questions and the interviewers then, according to the respondents' answers, put a $\sqrt{ }$ (check) mark on a corresponding number in the prepared checklist [9].

Originally, all districts in Batang Regency, Central Java, was planned to be used as a sample but due to research limitation, sample collection could only be taken from Subah District. The Slovin technique was applied on the 15-65 years old population in Subah to obtain a minimum sample of 396 people and an error margin of $5 \%$; however, only 83 respondents and $10.95 \%$ error margin was obtained since the limited time and fund did not allow for the targeted sample number.

\subsection{Data processing method}

Two comparative tests were used: first, the KruskalWallis test to identify differences in the impacts of infrastructure development among the three geographical zones; second, Mann Whitney test to identify differences in the impacts of infrastructure development among villagers who have stayed for more than 10 years and less than 10 years. 


\section{Results and discussion}

The survey questionnaires were given to 83 respondents among Batang Regency villagers consisting of 2 criteria namely geographical zone and duration of stay. With regards to the duration of stay, 77 respondents have lived in the area for more than 10 years while 6 respondents have lived there for less than 10 years. In terms of geographical zone, 42 respondents live along Pantura, 20 respondents live in the mountainous area and 21 respondents live in the coastal area.

The Kruskal Wallis comparative test was run on the geographical differences: if $\mathrm{H}$ calculation $>\chi^{2}$ then differences of impacts exist, and vice versa. The Mann Whitney comparative test was run on the differences in the length of stay: if value of $Z<$ table $Z$ then differences of impacts exists between villagers who have stayed for less than 10 years and those who have stayed for more than 10 years.

Table 1. Calculation results on social impacts

\begin{tabular}{|c|c|c|c|c|c|}
\hline \multirow[b]{2}{*}{ No } & \multirow[b]{2}{*}{ Remarks } & \multicolumn{2}{|c|}{ Kruskal Wallis } & \multicolumn{2}{|c|}{$\begin{array}{c}\text { Mann } \\
\text { Whitney }\end{array}$} \\
\hline & & $H$ calc. & $\begin{array}{c}\chi^{2} \\
\text { table } \\
\text { valu } \\
\text { e }\end{array}$ & $\begin{array}{c}\mathrm{Z} \\
\text { valu } \\
\mathbf{e}\end{array}$ & $\begin{array}{c}Z \\
\text { table } \\
\text { valu } \\
\text { e }\end{array}$ \\
\hline S1 & $\begin{array}{l}\text { Connection } \\
\text { among families }\end{array}$ & $\begin{array}{c}262.24 \\
0\end{array}$ & $\begin{array}{c}0.89 \\
7\end{array}$ & $\begin{array}{c}0.89 \\
7\end{array}$ & 1.96 \\
\hline S2 & $\begin{array}{l}\text { Connection with } \\
\text { family members } \\
\text { who are out of } \\
\text { town/living away } \\
\text { from home }\end{array}$ & 252.85 & $\begin{array}{c}0.41 \\
3\end{array}$ & $\begin{array}{c}0.41 \\
3\end{array}$ & 1.96 \\
\hline S3 & $\begin{array}{l}\text { Connection } \\
\text { among villagers }\end{array}$ & $\begin{array}{c}257.89 \\
0\end{array}$ & $\begin{array}{c}1.34 \\
5\end{array}$ & $\begin{array}{c}1.34 \\
5\end{array}$ & 1.96 \\
\hline S4 & $\begin{array}{l}\text { The intensity of } \\
\text { connections/visit } \\
\text { s to relatives' } \\
\text { houses }\end{array}$ & $\begin{array}{c}262.18 \\
0\end{array}$ & $\begin{array}{c}0.54 \\
5\end{array}$ & $\begin{array}{c}0.54 \\
5\end{array}$ & 1.96 \\
\hline S5 & $\begin{array}{l}\text { Coordination } \\
\text { among villagers } \\
\text { during social } \\
\text { activities/workin } \\
\text { g together }\end{array}$ & 0.000 & $\begin{array}{c}0.00 \\
0\end{array}$ & $\begin{array}{c}0.00 \\
0\end{array}$ & 1.96 \\
\hline S6 & $\begin{array}{l}\text { Sense of } \\
\text { togetherness } \\
\text { among villagers } \\
\text { during activities }\end{array}$ & 21.304 & $\begin{array}{c}0.75 \\
6\end{array}$ & $\begin{array}{c}0.75 \\
6\end{array}$ & 1.96 \\
\hline S7 & Criminal acts & 0.502 & $\begin{array}{c}0.00 \\
9\end{array}$ & $\begin{array}{c}0.00 \\
9\end{array}$ & 1.96 \\
\hline S8 & $\begin{array}{l}\text { Norms and } \\
\text { customs }\end{array}$ & 3.497 & $\begin{array}{c}0.70 \\
3\end{array}$ & $\begin{array}{c}0.70 \\
3\end{array}$ & 1.96 \\
\hline S9 & Village tradition & 9.599 & $\begin{array}{c}1.24 \\
8\end{array}$ & $\begin{array}{c}1.24 \\
8\end{array}$ & 1.96 \\
\hline $\begin{array}{c}\text { S1 } \\
0\end{array}$ & $\begin{array}{l}\text { The intensity of } \\
\text { social } \\
\text { activities/workin } \\
\text { g together } \\
\text { among villagers }\end{array}$ & -45.161 & $\begin{array}{c}1.31 \\
9\end{array}$ & $\begin{array}{c}1.31 \\
9\end{array}$ & 1.96 \\
\hline
\end{tabular}

\begin{tabular}{|c|l|c|c|c|c|}
\hline \multirow{2}{*}{ No } & \multicolumn{2}{|c|}{ Remarks } & \multicolumn{2}{|c|}{ Kruskal Wallis } & \multicolumn{2}{c|}{$\begin{array}{c}\text { Mann } \\
\text { Whitney }\end{array}$} \\
\cline { 3 - 6 } & $\begin{array}{c}\chi^{2} \\
\text { table } \\
\text { valu } \\
\text { e }\end{array}$ & $\begin{array}{c}\text { Z } \\
\text { valu } \\
\mathbf{e}\end{array}$ & $\begin{array}{c}\text { Z } \\
\text { table } \\
\text { valu } \\
\mathbf{e}\end{array}$ \\
\hline S1 & $\begin{array}{l}\text { The intensity of } \\
\text { religious } \\
\text { activities }\end{array}$ & 27.786 & $\begin{array}{c}0.47 \\
5\end{array}$ & $\begin{array}{c}0.47 \\
5\end{array}$ & 1.96 \\
\hline S1 & $\begin{array}{l}\text { Desire to move } \\
\text { to the city }\end{array}$ & 27.786 & $\begin{array}{c}0.14 \\
9\end{array}$ & $\begin{array}{c}0.14 \\
9\end{array}$ & 1.96 \\
\hline S1 & $\begin{array}{l}\text { Use of means of } \\
\text { communication } \\
\text { such as landline/ } \\
\text { hand phone/ } \\
\text { laptop }\end{array}$ & 0.638 & $\begin{array}{c}0.84 \\
4\end{array}$ & $\begin{array}{c}0.84 \\
4\end{array}$ & 1.96 \\
\hline S1 & $\begin{array}{l}\text { Use of internet } \\
\text { connection in } \\
\text { means of } \\
\text { communication }\end{array}$ & 10.632 & $\begin{array}{c}1.63 \\
5\end{array}$ & $\begin{array}{c}1.63 \\
5\end{array}$ & 1.96 \\
\hline S1 & $\begin{array}{l}\text { Signal for means } \\
\text { of } \\
\text { communication }\end{array}$ & 3.533 & 0.84 & 0.84 & 1.96 \\
\hline
\end{tabular}

Based on the Kruskal Wallis test in Table 1, variables S1-S4, S6, S9, S11, S12 and S14 possess H calculation > $\chi 2$ table, indicating that differences of impacts exist; while for variables S5, S7, S8, S10, S13 and S15, similar impacts exist. For the Mann Whitney test, $\mathrm{Z}$ values $>\mathrm{Z}$ table value for all variables, indicating similar impacts exist in all aspects.

Connection among family refers to how well the connection between spouses, parents and their children, among children, and among relatives. Based on the survey, the connection in the area along Pantura and coastal area improved but there was no influence from infrastructure development on the mountainous area; at the same time, the comparative tests showed no similar influence. With regards to the duration of stay, both categories of villagers who have lived in the area for less than 10 years and more than 10 years felt that the connection among family improved, while the comparative tests showed similar impacts. Sife, Kiondo, and Lyimo-Macha [10] concluded that infrastructure development in telecommunication can improve connection and therefore improve communication among families. Indrawati [11] concluded that the social economy status such as level of education, income and occupation influence the connection among family. These researches showed that apart from the increased use of means of communication, the level of income and education also increases; in turn, it can improve family connection.

Connection with family members who are out of town/living away from home refers to how well communication can be maintained if one or more family members (father/mother/children) are outside the village or living away from home. The survey showed that in the three geographical categories and the two durations of stay categories, connection was stated to be better. Interestingly, the comparative tests in the first category showed differences of impacts between the three areas 
while the median showed similar impacts. Therefore, it can be concluded that there are similar impacts in the three areas. This is in line with Rahman et al. [12], who stated that infrastructure development on telecommunication can maintain connection among family members living away from home. In our research, the villagers who were already using means of communication felt less worried about their family members living away from home since it became easier to reach them.

Coordination among villagers during social activities/working together refers to how well they manage technical and non-technical matters to ensure every activity runs smoothly. Sense of togetherness refers to how villagers conduct activities in a regular and integrated manner to reach common goals. Our research showed that coordination during activities in nearby Pantura, coastal, and mountainous areas became easier. Similarly, for the category of stay duration, they all stated that coordination was easier. At the same time, the comparative tests showed similar influences existing in the three areas and both categories of stay duration.

Near Pantura border, norms and customs improved while the opposite happened in coastal and mountainous area; the comparative tests showed that there are similar influences among the three areas. Villagers who have lived there for less than 10 years felt that norms and customs were fading while whose who have lived in the area for more than 10 years did not feel any significant changes in norms and customs; the comparative test showed similar impacts. Yanti [13] stated that norms can change because roads construction can lead to contact with other cultures. Our research identified fading norms and customs such as in manners towards parents and western-influenced style of clothes.

Table 2. Calculation results of impacts on economy

\begin{tabular}{|c|c|c|c|c|c|}
\hline \multirow[b]{2}{*}{ No } & \multirow[b]{2}{*}{ Remarks } & \multicolumn{2}{|c|}{ Kruskal Wallis } & \multicolumn{2}{|c|}{ Mann Whitney } \\
\hline & & $\begin{array}{c}\mathbf{H} \\
\text { calc. }\end{array}$ & $\begin{array}{c}\chi^{2} \\
\text { table } \\
\text { value }\end{array}$ & $\begin{array}{c}\mathrm{Z} \\
\text { value }\end{array}$ & $\begin{array}{c}Z \\
\text { table } \\
\text { value }\end{array}$ \\
\hline E1 & Level of income & 7.403 & 5.99 & 0.262 & 1.96 \\
\hline E2 & $\begin{array}{l}\text { Ease to find } \\
\text { jobs }\end{array}$ & 9.317 & 5.99 & 0.211 & 1.96 \\
\hline E3 & $\begin{array}{l}\text { Ease to find } \\
\text { information on } \\
\text { market prices }\end{array}$ & 1.796 & 5.99 & 0.229 & 1.96 \\
\hline E4 & $\begin{array}{l}\text { Ease to sell } \\
\text { agriculture, } \\
\text { farm, fisheries, } \\
\text { trading and } \\
\text { manufacturing } \\
\text { products }\end{array}$ & 4.010 & 5.99 & 0.331 & 1.96 \\
\hline E5 & $\begin{array}{l}\text { Benefits from } \\
\text { agriculture/farm } \\
\text { /fisheries/enterp } \\
\text { rises }\end{array}$ & 4.905 & 5.99 & 0.672 & 1.96 \\
\hline E6 & $\begin{array}{l}\text { Yields of } \\
\text { agriculture/farm } \\
\text { /fisheries }\end{array}$ & 4.369 & 5.99 & 0.721 & 1.96 \\
\hline E7 & $\begin{array}{l}\text { Participation of } \\
\text { housewives to }\end{array}$ & 4.092 & 5.99 & 0.384 & 1.96 \\
\hline
\end{tabular}

\begin{tabular}{|c|c|c|c|c|c|}
\hline \multirow[b]{2}{*}{ No } & \multirow[b]{2}{*}{ Remarks } & \multicolumn{2}{|c|}{ Kruskal Wallis } & \multicolumn{2}{|c|}{ Mann Whitney } \\
\hline & & $\begin{array}{c}\mathbf{H} \\
\text { calc. }\end{array}$ & $\begin{array}{c}\chi^{2} \\
\text { table } \\
\text { value }\end{array}$ & $\begin{array}{c}\mathbf{Z} \\
\text { value }\end{array}$ & $\begin{array}{c}Z \\
\text { table } \\
\text { value }\end{array}$ \\
\hline & $\begin{array}{l}\text { increase family } \\
\text { income }\end{array}$ & & & & \\
\hline E8 & $\begin{array}{l}\text { Household daily } \\
\text { expenses }\end{array}$ & 5.006 & 5.99 & 0.410 & 1.96 \\
\hline E9 & Price of land & 2.849 & 5.99 & 0.801 & 1.96 \\
\hline E10 & $\begin{array}{l}\text { Travel time to } \\
\text { reach nearest } \\
\text { market }\end{array}$ & 1.765 & 5.99 & 0.255 & 1.96 \\
\hline E11 & $\begin{array}{l}\text { Travel time to } \\
\text { reach nearest } \\
\text { city center }\end{array}$ & 1.765 & 5.99 & 0.255 & 1.96 \\
\hline E12 & $\begin{array}{l}\text { Travel time to } \\
\text { reach place of } \\
\text { livelihood }\end{array}$ & 2.878 & 5.99 & 0.149 & 1.96 \\
\hline
\end{tabular}

Table 2 shows that variables E1 and E2 in the Kruskal Wallis test has $\mathrm{H}$ value $>\chi^{2}$ table value, indicating differences of impacts, while variables E3-E12 showed similar impacts. The Mann Whitney test showed $Z$ value $>Z$ table value for all variables, indicating similar impacts across all categories.

The increased income is in accordance with Sife, Kiondo, and Lyimo-Macha [10] research, which stated that community income would increase after infrastructure development in telecommunication due to increased efficiency and decreased cost of transportation, ease to check market prices and ease to sell products directly to buyers instead of middlemen. Another research by Yanti [13] stated that income increase would be generated due to road construction, which could decrease travel time. In addition, Aritonang, Tarigan, and Purwoko [14] stated that income increase would be generated after the development of irrigation infrastructure since water sources would become readily available for farmers.

Table 3. Calculation results for education impacts

\begin{tabular}{|c|l|c|c|c|c|}
\hline \multirow{2}{*}{ No } & \multirow{2}{*}{ Remarks } & \multicolumn{2}{|c|}{ Kruskal Wallis } & \multicolumn{2}{|c|}{$\begin{array}{c}\text { Mann } \\
\text { Whitney }\end{array}$} \\
\cline { 3 - 6 } & H calc. & $\begin{array}{c}\chi \mathbf{2} \\
\text { table } \\
\text { value }\end{array}$ & $\begin{array}{c}\mathbf{Z} \\
\text { value }\end{array}$ & $\begin{array}{c}\mathbf{Z} \\
\text { table } \\
\text { value }\end{array}$ \\
\hline P1 & $\begin{array}{l}\text { Community's } \\
\text { level of } \\
\text { education }\end{array}$ & 0.139 & 5.99 & 0.106 & 1.96 \\
\hline P2 & $\begin{array}{l}\text { Learning } \\
\text { activities at } \\
\text { schools }\end{array}$ & 0.035 & 5.99 & 0.053 & 1.96 \\
\hline P3 & $\begin{array}{l}\text { Access to reach } \\
\text { schools }\end{array}$ & 0.314 & 5.99 & 0.158 & 1.96 \\
\hline P4 & $\begin{array}{l}\text { Schools' } \\
\text { physical } \\
\text { condition }\end{array}$ & 0.841 & 5.99 & 0.276 & 1.96 \\
\hline P5 & $\begin{array}{l}\text { Number of } \\
\text { schools }\end{array}$ & 16.744 & 5.99 & 0.783 & 1.96 \\
\hline
\end{tabular}

Table 3 shows that variable P5 in the Kruskal Wallis has $\mathrm{H}$ value $>\chi^{2}$ table value, indicating differences of 
impacts exist, while variables P1-P4 showed similar impacts. Meanwhile in the Mann Whitney test, $Z$ value $>$ $\mathrm{Z}$ table value, indicating similar impacts.

Community's level of education increased in line with the increase of income. In addition, better roads mean easier access to reach schools, leading to an increase in the villagers' desire for education. The community also felt improvement in learning activities due to better school infrastructure. Although the number of schools did not increase, the physical improvement better supported learning activities.

Table 4. Calculation results on health impacts

\begin{tabular}{|c|c|c|c|c|c|}
\hline \multirow[b]{2}{*}{ No } & \multirow[b]{2}{*}{ Remarks } & \multicolumn{2}{|c|}{ Kruskal Wallis } & \multicolumn{2}{|c|}{$\begin{array}{c}\text { Mann } \\
\text { Whitney }\end{array}$} \\
\hline & & $H$ calc. & $\begin{array}{c}\chi^{2} \\
\text { table } \\
\text { value }\end{array}$ & $\begin{array}{c}Z \\
\text { value }\end{array}$ & $\begin{array}{c}Z \\
\text { table } \\
\text { value }\end{array}$ \\
\hline K1 & $\begin{array}{l}\text { Shorter travel } \\
\text { time to reach } \\
\text { health centers }\end{array}$ & 1.765 & 5.99 & 0.255 & 1.96 \\
\hline K2 & $\begin{array}{l}\text { Ease of } \\
\text { emergency } \\
\text { health care } \\
\text { when needed }\end{array}$ & 1.102 & 5.99 & 0.369 & 1.96 \\
\hline K3 & Health services & 0.035 & 5.99 & 0.000 & 1.96 \\
\hline K4 & $\begin{array}{l}\text { Use of health } \\
\text { facilities for } \\
\text { childbirth }\end{array}$ & 0.558 & 5.99 & 0.492 & 1.96 \\
\hline K5 & $\begin{array}{l}\text { Use of health } \\
\text { facilities to treat } \\
\text { illnesses }\end{array}$ & 0.314 & 5.99 & 0.563 & 1.96 \\
\hline
\end{tabular}

Table 4 shows that variables $\mathrm{K} 1-\mathrm{K} 5$ of the Kruskal Wallis contains $H$ value $<\chi 2$ table value, indicating similar impacts. At the same time, the Mann Whitney test showed $\mathrm{Z}$ value $>\mathrm{Z}$ table value, indicating similar impacts.

Infrastructure development in telecommunication made communication easier for villagers during health emergency. An example is during childbirth; medical service could be notified promptly and therefore arrived in time to lower the risk of maternal death. In addition, the increased use of health facilities is also an indicator of improvement caused by health infrastructure development: villagers who used to enlist traditional treatments for illness or childbirth now prefer to go to existing health facilities.

\section{Conclusion}

This research discusses the impacts of village infrastructure development such as roads, irrigation, telecommunication, electricity, health, education, and drinking water in Batang Regency, Central Java. The results showed similar impacts in mountainous and coastal areas in terms of economy, education, and health aspects but differences exist in terms of social impacts. Based on the length of stay, there were no differences of impacts for those who have stayed for more than 10 years and less than 10 years.
Batang Regency, Central Java, consists of 248 villages with mountainous and coastal landscapes, as well as areas along Pantura. Most of its land is utilized for agriculture and is highly potential for strong economic growth with the support of village fund. The majority of the fund is used for infrastructure development, which, as this research showed, improved the level of economy and education without worsening village environment. Nonetheless, in the social aspect, degradation of norms and culture could be found such as in the form of loss tradition during harvesting peak and behaviors negatively influenced by outside culture. The researchers suggest community and village apparatus to improve character education at schools and strengthen village tradition to counter these negative effects.

The authors would like to acknowledge funding support from PITTA Grant No. 2386/UN2.R3.1/HKP.05.00/2018 for conducting research and disseminating research results.

\section{References}

1. R. A. Maulana, Analisa Dampak Sosial-Ekonomi Infrastruktur Jawa - Sumatera, Jakarta Selatan: Badan Penelitian dan Pengembangan, Kementrian Pekerjaan Umum dan Perumahan Rakyat (2013)

2. Sekretariat Kabinet Republik Indonesia, Dana desa, Pemerintahan Jokowi Wujudkan Kedaulatan desa, accessed on June 6, 2017. http://setkab.go.id/danadesa-pemerintahan-jokowi-wujudkan-kedaulatandesa/ (2016)

3. Kementerian Keuangan Republik Indonesia, Mandiri Membangun desa sendiri, Accessed on June 6 , 2017 , https://www.kemenkeu.go.id/media/4964/mediakeuangan-edisi-mei-2017.pdf (2017)

4. A. Rahman, Perubahan Budaya Bergotong Royong Masyarakat di Desa Santan Tengah Kecamatan Marangakyu, eJournalSosiatri-Sosiologi 4, 1, pp. 86-99 (2016)

5. D. T. Tikson, Keterbelakangan dan ketergantungan: teori pembangunan di Indonesia, Malaysia, dan Thailand (2005)

6. Soekartawi, Pembangunan Pertanian, Depok: Raja Grafindo Persada (1995)

7. K. D. Indarto, S. Rahayu, Dampak Pembangunan Perumahan Terhadap Kondisi Lingkungan, Sosial dan Ekonomi Masyarakat Sekitar di Kelurahan Sambiroto, Kecamatan Tembalang, Teknik PWK (Perencanaan Wilayah Kota) 4, 3, pp. 428-439 (2015)

8. E. Marinho, G. Campelo, J. França, J. Araujo, Impact of Infrastructure Expenses in Strategic Sectors for Brazilian poverty, Economia, 18, 2, pp. 244-259 (2017)

9. S. Siregar,. Metode penelitian kuantitatif dilengkapi dengan perbandingan perhitungan manual \& SPSS, Jakarta: Kencana Prenada Media Group (2013)

10. A. S. Sife, E. Kiondo, J. G. Lyimo-Macha, Contribution of mobile phones to rural livelihoods and poverty reduction in Morogoro region, Tanzania, The Electronic Journal of Information 
Systems in Developing Countries 42, 1, pp. 1-15 (2010)

11. E. S. Indrawati, Status Sosial Ekonomi dan Intensitas Komunikasi Keluarga Pada Ibu Rumah Tangga di Panggung Kidul Semarang Utara, Jurnal Psikologi 14, 1, pp. $52-57$ (2015)

12. A. Rahman, M. N. Abdullah, A. Haroon, R. B. Tooheen, ICT impact on socio-economic conditions of rural Bangladesh, Journal of World Economic Research 2, 1, pp. 1-8 (2013)

13 A. T. D. Yanti, Dampak Kebijakan Pembangunan Jembatan Suramadu Terhadap Sosial Ekonomi Masyarakat Dalam Pengembangan Wilayah Jembatan Suramadu (Studi Di Desa Sukolilo Barat Kecamatan Labang Kabupaten Bangkalan), Jurnal Administrasi Publik 1, 2, pp. 147-154 (2013)

14. D. O. P. Aritonang, R. Tarigan, A. Purwoko, Dampak Pembangunan Daerah Irigasi Lobutua Terhadap Pengembangan Wilayah di Kecamatan Lintong Nihuta Kabupaten Humbang Hasundutan, Jurnalkonom 17, 2 (2014)

15. M. S. A. Nasution, M. N. H. Daulay, N. Susanti, S. Syam, Ilmu Sosial Budaya Dasar, Jakarta: Rajawali Pers (2015)

16. Z. Nasution, Konflik dan Lunturnya Solidaritas Sosial Masyarakat Desa Transisi, Accessed on June 6, 2017, http://berkarya.um.ac.id/konflik-danlunturnya-solidaritas-sosial-masyarakat-desatransisi-oleh-zulkarnain-nasution/ (2010)

17. M. Lokshin, R. Yemtsov, Has rural infrastructure rehabilitation in Georgia helped the poor?, The World Bank Economic Review 19, 2, pp. 311-333 (2005) 